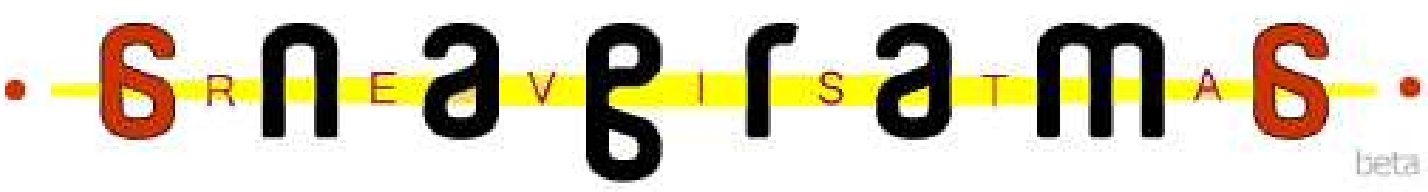

\section{Tomie Ohtake na Arte Contemporânea}

\section{Alline Corona Gallo ${ }^{1}$ \\ Orientação: Prof. Dr. Alekandre Huady Torres Guimarães}

\section{Resumo}

Diante da obra desta artista nipo-brasileira, o presente trabalho objetiva analisar os traços de contemporaneidade em parte das obras produzidas por Ohtake quando do Centenário da Imigração Japonesa. Este artigo foi desenvolvido no período de agosto de 2008 e julho de 2009 e designaremos nesta pesquisa a vida e a obra da artista, com o objetivo de mostrar toda a sua trajetória e conquista de sua carreira. Os dados concretos e de valor para se referir à artista selecionada tem como pretensão contribuir com os estudos sobre a arte brasileira contemporânea na atualidade.

Palauras-chaue: Arte, Tomie Ohtake, Contemporâneo.

\section{Introdução}

Este artigo esta direcionado para caracterizar as obras de Ohtake como parte da Arte Contemporânea e discutir um pouco da imigração japonesa e as obras de comemoração do Centenário da Imigração Japonesa compostas pela Ohtake.

$\mathrm{Na}$ atualidade, Tomie Ohtake é considerada uma das principais representantes do Abstracionismo informal brasileiro, cuja obra abrange pinturas, gravuras e esculturas. Estas obras mostram um aspecto de fortes sentimentos e emoções em conjunções de formas e cores criadas mais livremente.

Tomie Ohtake nasceu em 21 de novembro de 1913 e, desde pequena, percebeu que o caminho da arte sempre estava à sua frente. Na escola, onde tinha o maior contato com a arte, percebeu que da caligrafia de ideogramas para o desenho, a distância poderia ser

\footnotetext{
${ }^{1}$ Aluna do curso de Publicidade e Propaganda da Universidade Presbiteriana Mackenzie
} 
muito pequena. Esta arte de escrever com figuras foi um dos grandes incentivos para que Tomie Ohtake percebesse qual era a sua vocação.

Quando chegou ao Brasil, com 23 anos de idade, para visitar seu irmão, pensou em permanecer no país apenas por um ano ou dois, para em seguida voltar ao Japão, sua terra natal, o único lugar que conhecia e onde pretendia ficar por toda vida.

Durante sua estada no Brasil, a situação do outro lado do oceano começou a ficar incerta frente à realidade política mundial da época, quando vários adventos se transformaram no evento que mais tarde denominou-se como II Guerra Mundial.

Em virtude desse evento bélico, Tomie Ohtake, pouco mais que uma adolescente, viu-se forçada a prolongar sua permanência no Brasil durante o período em que a II Guerra Mundial não só eclodiu, mas durou e chegou ao seu final, época esta em que Ohtake se casou com um engenheiro agrônomo e, a partir de então, tomou o Brasil por sua segunda pátria.

Tomie voltou pela primeira vez ao Japão em 1951, para ver sua mãe doente. Há dez anos não visita o país, apesar de ter mantido a frequiência de uma viagem a cada quatro anos.

Do Japão para o Brasil e do Brasil para o mundo. Assim se resume a trajetória da artista plástica Tomie Ohtake, que nasceu no Japão e aportou em Santos em 1936, depois de longos 45 dias de viagem marítima. É como se as paisagens do campo e da cidade desfilassem diante dos olhos de Tomie junto de sua sensibilidade por décadas. Até que um dia ela começa a converter seu amor pela arte em telas e esculturas monumentais, a partir de cores e formas valorizadas por sua simplicidade. (Rego, 2001:32)

As cores parecem guiar a vida da nipo-brasileira de 94 anos, que virou informalmente a artista das comemorações do Centenário da Imigração Japonesa no Brasil.

Além das obras para o centenário, Tomie também assinou, entre diversos outros trabalhos, os cenários e figurinos da ópera Madame Butterfly, encenada em junho de 2008, no Teatro Municipal de São Paulo, como fez na década de 1980 para o Teatro Municipal do Rio de Janeiro. A história conta o trágico romance de uma jovem gueixa com um capitão da marinha norte-americana, no Japão do final do século 19.

Se no Japão, Ohtake nunca teve à sua frente um professor de pintura, no Brasil a situação era pior. Casada em tenra idade, tornou-se dona de casa, em uma sociedade fechada, de costumes milenares, dentro qual a mulher era submissa e limitada a um círculo restrito de amizades e de participação. 
Depois de muito tempo de arte hibernada, Tomie Ohtake começou a desanimar com o trabalho artístico, o qual achava ser só um sonho. Aos 31 anos de idade o sonho revigorou quando encontrou, em 1951, com o artista japonês Keisuke Sugano, que acabara de chegar do Japão, país onde a arte tinha muito mais valor, e estava apenas de passagem pelo Brasil.

O desabrochar da arte de Tomie, em 1951, se deu com a fase figurativista, o que é perfeitamente compreensível, pela influência de seu primeiro e único professor, crítico severo de seu trabalho, condicionando-lhe, de certa maneira a fluidez do estilo e da arte tão inspiradora. (VICTORINO, Paulo)

Foi com este encontro que Ohtake passou a datar seus primeiros quadros, ainda tímidos na cor, mas emocionantes na essência. Auxiliada por Sugano, a artista compôs suas primeiras obras, simples pinturas figurativas, depois, algumas paisagens com inclinação para o Fauvismo e outras experiências já com a presença do Cubismo. A maior parte dos quadros pintados nessa primeira fase artística de Ohtake perdeu-se numa das enchentes, tão comuns em certas regiões de São Paulo.

Sugano, Keisuke: artista plástico japonês que durante sua exposição no Brasil, conheceu Ohtake e a ajudou a descobrir sua arte e fazer parte do grupo Seibi, do qual já fazia parte.

Dois anos depois deste encontro, Ohtake já participava de uma exposição do Grupo Seibi (Seibikai, em japonês), uma associação de japoneses na zona sul de São Paulo, com existência legal desde o ano de 1935 e bastante prestigiada pela colônia. Os trabalhos de Ohtake, sempre abstratos, conquistaram galerias do Brasil e do exterior. Brincando com as cores e formas, a artista passou a transitar, sem dificuldades, pela pintura, gravura e escultura.

Sua primeira aparição pôde ser suficientemente notada, recebendo do júri menção honrosa. Sua presença também foi marcante nas mostras dos anos seguintes, chegando a receber, em duas ocasiões, medalhas de ouro.

A história da imigração japonesa está ligada diretamente à artista, pois com a vinda dos japoneses para o Brasil, o olhar Europeu voltou para esta terra Latina e fez com o seu professor passasse por aqui e conhece Tomie Ohtake.

A abolição da escravatura no Brasil em 1888 dá novo impulso à vinda de imigrantes europeus, cujo início se deu com os alemães em 1824. Em 1895 é assinado o Tratado de Amizade, Comércio e Navegação entre o Brasil e o Japão. Um ano antes, o 
deputado japonês Tadashi Nemoto estivera no Brasil e recomendou o envio de japoneses ao Brasil, fato que atendia a uma necessidade do Japão que passava por dificuldades econômicas. Inicia-se uma campanha para encorajar os japoneses a imigrarem. O Peru recebeu os imigrantes antes, mas por falta de infra-estrutura, muitos deles fugiram para o Brasil.

O governo do estado de São Paulo deu apoio à vinda dos japoneses, e em 1906, Ryu Mizuno, da Companhia Imperial de Imigração chegou para inspecionar regiões agrícolas, acompanhado de Teijiro Suzuki.

Mizuno retorna ao Brasil no ano seguinte e assina acordo com o governo do estado de São Paulo, para a introdução de três mil imigrantes nos próximos três anos. Cinco intérpretes que vão acompanhar os trabalhadores do primeiro navio de imigrantes japoneses a aportar no Brasil chegam a Santos.

Com 781 japoneses a bordo, o navio Kasato-maru aporta em Santos. De lá eles são transportados para a hospedaria dos imigrantes, em São Paulo, onde são divididos em seis grupos. A imigração na cafeicultura começa com péssimos resultados. Um ano depois, dos 781 imigrantes, apenas 191 permanecem nos locais de trabalho. A maioria estava em São Paulo, Santos e Argentina. Apesar disso, a imigração continua com a chegada da segunda leva de imigrantes em 1910.

Considerada a dama das artes plásticas, Tomie começou a carreira artística aos 40 anos. A partir daí vieram participações na Bienal de São Paulo e exposições na Itália, Japão, Estados Unidos. Suas obras estão entre as mais valiosas de artistas brasileiros vivos (EZABELLA, 2008).

\section{Referencial teórico}

A Arte brasileira contemporânea possui uma história tão longa quanto à dos países considerados culturalmente hegemônicos. As primeiras manifestações da arte contemporânea brasileira ocorreram na passagem da década de 1950 para a de 1960. Dela participam umas quatro gerações ou safras de artistas que aqui produziram e hoje emprestam sentido genealógico às gerações mais novas. Geração em que Ohtake faz parte e mostra a sua arte para os novos artistas.

A Arte Contemporânea é caracterizada pela reunião de uma notável diversidade de estilos, movimentos e técnicas. Devido a essa diversidade é difícil definir a arte contemporânea incluindo toda a arte produzida no século XX. Para alguns críticos, a característica mais importante da arte contemporânea é sua tentativa de criar pinturas e 
esculturas voltadas para si mesmas e, assim, distinguir-se das formas de arte anteriores, que transmitiam idéias de instituições políticas, religiosas entre outras.

Os anos 60 foram decisivos para a maturação do trabalho de Tomie Ohtake. Neste período, toda a técnica de seu trabalho conflui-se com a sua personalidade. No ano de 1960 foi premiada no Salão Nacional de Arte Moderna e no ano seguinte participou pela primeira vez da Bienal Internacional de São Paulo. No final da década começou a trabalhar com serigrafia e posteriormente passou a executar gravuras em metal e litografias, que já em 1972 foram exibidas na Bienal de Veneza ao lado de nomes consagrados internacionalmente. (Tomie Ohtake: 50 anos de arte)

Se o aprendizado com o pintor Keisuke Sugano, elementar e de curta duração, não lhe rendeu maiores dividendos, pelo menos, trouxe a vantagem de tirar Tomie do isolamento em que se encontrava. Ninguém mais lhe negava o mérito, ninguém lhe obstava os passos, podendo seguir, com relativa liberdade, o destino que lhe estava traçado. $\mathrm{O}$ encontro com o professor Ohtake deu-se em 1951 e, desse ano, datam seus primeiros quadros, ainda tímidos e vacilantes.

O Seibikai trazia uma restrição, que era a de aceitar única e tão somente obras de artistas japoneses ou descendentes. Mas trazia, também, uma amplitude não comum em exposições, pois, ao mesmo tempo em que expunha quadros de pintores já consagrados, aceitava também obras de iniciantes. Os primeiros atraiam o público para a exposição, os outros se beneficiavam dessa presença credenciada de visitantes, entre eles jornalistas e críticos de arte japoneses, radicados no Brasil.

Ohtake não tardou em seguir seu caminho próprio, fazendo experiências fauvistas, cubistas e enveredando, depois, para o Concretismo, e mergulhando por inteiro no Abstracionismo, onde permaneceria definitivamente, mas sempre fiel à forma, ao desenho bem caracterizado, à aplicação das cores de uma maneira racional e organizada.

Fauvismo é a nomenclatura concedida à tendência estética na pintura que buscou explorar ao máximo a expressividade das cores na representação pictórica. A tendência fauvistas não só revolucionou o uso das cores na pintura moderna como foi uma das origens dos posteriores movimentos de ruptura estética nas artes plásticas. O uso pejorativo da expressão, que pode significar os animais selvagens, prevaleceu nas críticas imediatamente posteriores. Apesar da negação do rótulo e dos protestos pelos artistas integrados à nova tendência, que não chegaram a lançar nenhum manifesto teórico de afirmação e nomeação da sua linha estética, o termo Fauvismo acabou permanecendo, talvez indevidamente, nos estudos da história da arte. 
O Cubismo tratava as formas da natureza por meio de figuras geométricas, representando todas as partes de um objeto no mesmo plano. A representação do mundo passava a não ter nenhum compromisso com a aparência real das coisas. O Cubismo teve uma influência profunda na História da Arte, particularmente sobre tendências posteriores, como o Abstracionismo geométrico e o Minimalismo.

E o Concretismo é um movimento vanguardista surgido em 1950, primeiramente na música, passando para a poesia e artes plásticas. É assinalado pelo uso de figuras geométricas e pela elaboração baseada no raciocínio. Os princípios do Concretismo distanciam da arte qualquer sentido lírico ou simbólico. O quadro, construído com elementos plásticos, não tem outro significado a não ser ele próprio. $\mathrm{O}$ movimento defende a racionalidade e rejeita o Expressionismo, o acaso, a abstração lírica e aleatória. O intuito das obras é acabar com a distinção entre forma e conteúdo e criar uma nova linguagem. Essa concepção de arte não representa a realidade, mas evidencia estruturas, planos e conjuntos relacionados.

Independentemente de critérios e avaliações, a arte é a forma mais pura de transmitir os pensamentos do artista. E toda a arte de Ohtake responde perfeitamente a todas as suas fases de espírito fazendo com que ela possa se enquadrar no Abstracionismo Informal que faz parte da Arte Contemporânea.

Resulta dessa preocupação uma pintura agradável de ver, podendo ser apreciada e reconhecida mesmo por aqueles que torcem o nariz para o Abstracionismo. Há, pois, uma fácil e completa interação entre o observador e a obra, independentemente de seus conhecimentos técnicos ou de sua familiaridade com o estilo (VICTORINO, 2008)

A pincelada de Ohtake, não só representa uma característica sua, mas uma inovação no estilo de pintura ocidental. O compasso mais pausado e intervalado contrasta, por exemplo, com a maneira veloz na composição. E para construir suas pinturas, Ohtake altera a materialidade de suas telas, raspando parte dessas e procurando mais uma coloração além da dependência da tinta. Na década de 60, alguns de seus quadros resultam na adição de camadas sobre a figura, que propõem o engelhar pictórico e uma nova forma de solidez. Os tons de cada tela podiam chegar a uma perigosa suavidade e na outra emergir cores de intensos contrastes (Mendonça, 1983, p.143).

Na década de 70, Tomie Ohtake inicia as composições abstratas entre curvas, elipses, círculos, cápsulas. É nessa fase que Frederico Morais sugere uma conexão com o erótico, pelas formas criadas. Não um erótico concreto, mas a sensação erótica que é 
promovida pela complexidade de pintura e a ligação de sua forma, com o universo fisiológico e reprodutivo, uterino.

Morais, Frederico: renomado crítico de arte, considerado como crítico criador que escreveu sobre vários artistas incluindo Ohtake.

Entre as formas criadas pela artista, nas diversas etapas de sua obra, algumas podem ser vistas como eventualmente eróticas, permitindo analogias fálicas, vaginais, uterinas, mas, ainda sim, mais alusivas que intencionalmente figuradas (MORAIS, 2001, p.143).

Durante a sua carreira Ohtake realizou diversas obras públicas, como o painel pintado no Edifício Santa Mônica, na Ladeira da Memória, em São Paulo; a escultura Estrela do Mar, na Lagoa Rodrigo de Freitas, no Rio de Janeiro; a escultura em homenagem aos oitenta anos da imigração japonesa no Brasil, painéis para o Memorial da América Latina, para a estação Consolação do Metrô, em São Paulo, para o Colégio Maria Imaculada em São Paulo.

\begin{abstract}
A pintura de Tomie Ohtake se desenvolve a partir das linguagens abstratas. Assim, da tendência informal que a caracteriza em fins dos anos 50 evolui para um abstracionismo gestual explorador da espacialidade em início dos anos 60, aventurando-se por telas de maior dimensão, pesquisando a cor e texturas com uma finura que marcaria sua contribuição. E dos inícios de 60 uma série de grande poética na qual se utiliza de fluente gestualidade com sensível redução cromática - ao máximo três tons de cor quase invariavelmente. Desse período surgirá toda uma fase de sobreposição de planos em ortogonal sobre a base da tela, com o materialismo e transparência cromáticas se impondo em composições sóbrias, de caligrafia visível, já denunciando sua vocação para a manipulação de uma ampla espacialidade. A presença do geometrismo dominando forma versus fundo, sempre com um tratamento pictórico elaborado, emergirá em inícios dos anos 70, e é por essa época que se define sua predileção por suportes de superfícies quadradas de grande vastidão espacial. A curva se insinua aos poucos dominando as superfícies das telas com refinadas transparências (AMARAL, 1988. p. 307).
\end{abstract}

Artista consagrada, aplaudida e reconhecida pela crítica, recebeu inúmeros e significativos prêmios: melhor pintor do ano em 1974, 1979 e 1983, e em 2001 o prêmio personalidade artística do ano da Associação Paulista de Críticos de Arte. Em 1995 conquistou o Prêmio Nacional de Artes Plásticas do Ministério da Cultura e em 2008 recebeu o Grande Prêmio da Crítica de Artes Visuais da APCA.

Em sua influência abstracionista, Tomie Ohtake foge da materialidade e da representação de objetos convencionais. Sua pintura é mais sugestiva, incita a construção de arquétipos, o que alimenta a subjetividade através do inconsciente. Não há a racionalidade das formas, nem a mecanização estética. Contrariamente, a introspecção e a 
soltura, são suas características. A confluência de perspectivas, onde tonalidades diferentes confundem os planos e fundos das telas são evidentes, principalmente nos anos 90. Seu cromatismo abarca cores foscas e vivas. Mas há quase sempre a variação de tons numa mesma composição. Desde os pretos mais fechados, a cinzas, azuis, ocres, vermelhos e brancos. E o dégradé se presencia, não numa ordem de clareamento ou escurecimento óbvio, mas na troca de intensidades esparsas nas telas da artista, agregando inclusive manchas como parte intencional.

A artista enfatiza, em entrevistas, a importância da arte oriental, em especial a japonesa, em sua pintura, afirmando que "essa influência se verifica na procura da síntese: poucos elementos devem dizer muita coisa". (ARRUDA, 2000, p. 65.) Da tradição japonesa, Ohtake diz inspirar-se na noção de tempo do ukiyo-e (imagens do mundo que passa), arte que revela cenas de uma beleza fugaz. Pesquisa constantemente as possibilidades expressivas da pintura: as transparências, as texturas e a vibração da luz. Declara fazer uma pintura silenciosa, como a cidade em que nasceu. Em suas obras, revela um intenso diálogo entre a tradição e a contemporaneidade.

Em 2000, foi lançado em São Paulo o projeto do Instituto Tomie Ohtake, idealizado e coordenado por Ricardo Ohtake e projetado por Ruy Ohtake, Aos 88 anos, Tomie continua fazendo arte e inspirando novos e consagrados artistas com suas cores e formas. (Tomie Ohtake: 50 anos de arte.)

Erguido na mais importante cidade da América Latina, São Paulo, tem como proposta apresentar as novas tendências da arte nacional e internacional, além daquelas que são referências nos últimos 50 anos. Conta com $7.500 \mathrm{~m} 2$ para exposições de artes plásticas, arquitetura e design, salas específicas para ateliês, seminários e documentação, restaurante, livraria e loja de objeto e mais $6.500 \mathrm{~m} 2$, ainda em construção, para dois teatros e um cinema que contemplarão música, artes cênicas e áudio-visual.

A naturalidade com que Tomie se aproximava da técnica, assimilando-a sem esforço nem afetação, fez dela uma artista singular, que foi rapidamente notada e reverenciada nos Salões de que participou, dentro e fora do país. 


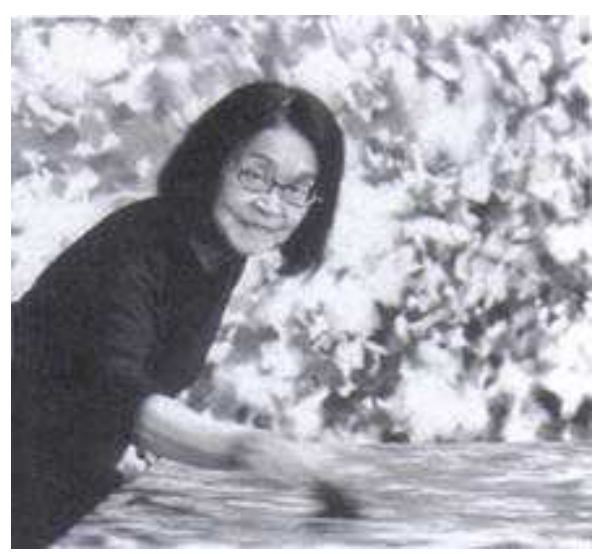

"Eu nunca pintei com o emocional. Sempre pintei mais friamente. É sempre colocando camada, camada, camada. Colocando muitas cores, camada, camada, até chegar onde eu quero" (OHTAKE, 2001, p 62).

Em 1957, seis anos depois de começar a pintar, já realizava sua primeira individual no Museu de Arte Moderna de São Paulo. Foi presença constante de exposições anuais dentro e fora do país. Em 1986, o Museu de Arte de São Paulo realizou uma retrospectiva de sua obra. Igual feito foi repetido em 1996 pela Bienal de São Paulo.

\begin{abstract}
As obras de Tomie Ohtake também ganharam as ruas de cidades brasileiras como Brasília, Curitiba, Rio de Janeiro e principalmente São Paulo, onde já se incorporaram à paisagem. É o caso da escultura de 40 metros que ocupa parte do canteiro central da Avenida 23 de Maio. (Do G1, com informações do Bom Dia São Paulo. Tomie Ohtake prepara surpresa para os cem anos de imigração.)
\end{abstract}

Em comemoração ao centenário da imigração japonesa que ocorreu ano passado, Ohtake presenteou a cidade com algumas esculturas. Uma nomeada de " $\mathrm{O}$ monumento do centenário". O monumento tem 9 metros de altura, devendo consumir cerca de 20 toneladas de chapa metálica e foi erguida próxima a via de acesso de embarque e desembarque do Aeroporto Internacional de São Paulo/Guarulhos Governador André Franco Montoro, considerado o aeroporto com maior movimento internacional do Brasil e o terceiro em tráfego doméstico.

Idealizado na cor vermelha, o monumento tem recortes no formato de ondas e estrutura de aço, com cerca de 9 metros de diâmetro. O evento de lançamento, realizado no Terminal de Passageiros do aeroporto, teve show das cantoras Karen Ito e Mariko Nakahira, e apresentação de grupo de taiko e dança do Centenário.

O objetivo da construção deste monumento é deixar para as futuras gerações uma obra marcante e durável para lembrar o centenário que foi comemorado ano passado. É um grandioso projeto, de imenso impacto e importância histórica. 


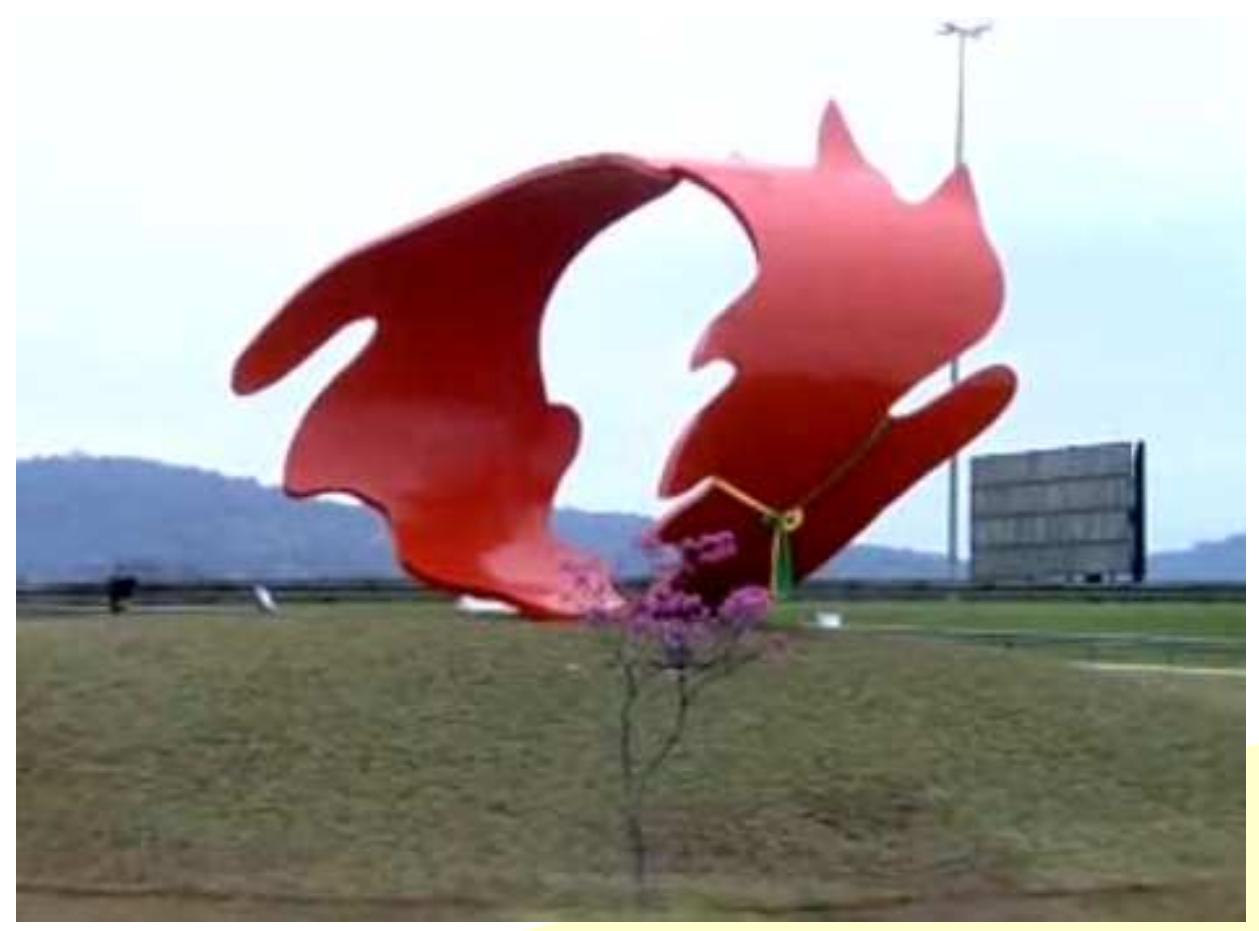

Outra obra foi a homenagem da cidade ao Centenário da Imigração Japonesa e foi inaugurada em junho do ano passado com a presença do príncipe herdeiro japonês Naruhito, marcando o ponto alto das comemorações em Santos pela data. A escultura integra o projeto 'As Ondas Santos 21', um amplo parque público que a prefeitura está construindo no Emissário Submarino - projeto assinado por Ruy Ohtake, filho de Tomie.

A instalação foi acompanhada pelos arquitetos Jorge Utsunomiya e Vera Fujisaki, da equipe de Tomie. No total, a peça é composta por 15 metros de altura, confeccionados com aço material de alta durabilidade, doado pela Cosipa/Usiminas e também com patrocínio da Gafisa.

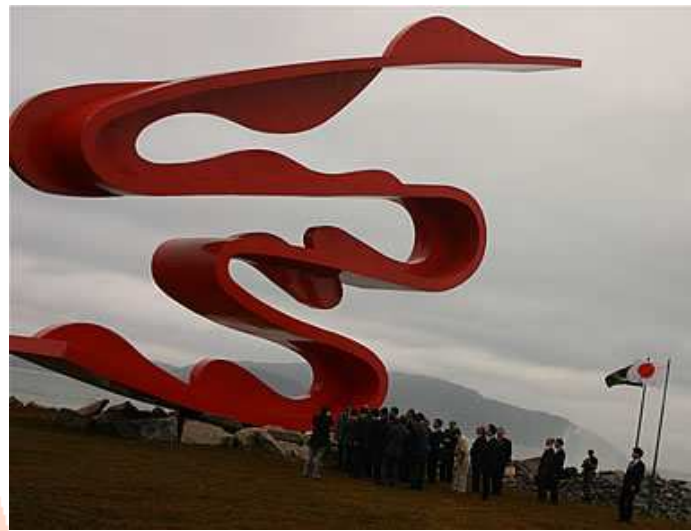




\section{Metodologia}

Como foi dito, a vida fez com que Ohtake enfrentasse a dura realidade de estar em um novo país e longe de toda a sua cultura. Casou-se com outro imigrante e constituiu sua família, criando seus filhos com a cultura que aprendera no Japão e convivendo com a cultura brasileira.

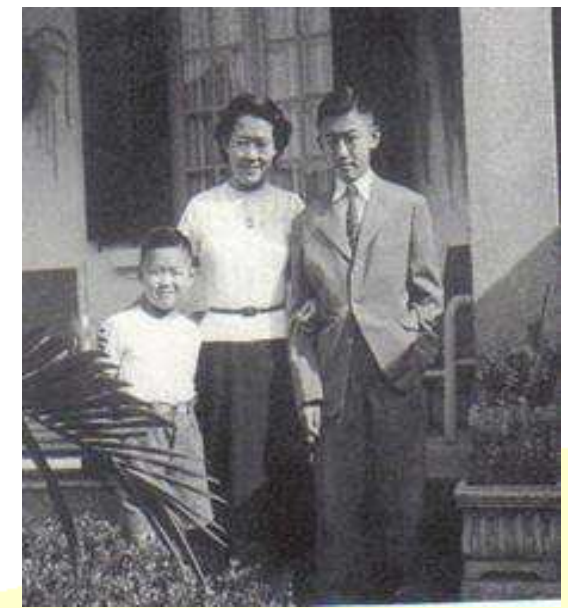

No livro Tomie Cerejeiras da Noite nos deparamos com as histórias da família Ohtake e da infância de Tomie - as doenças, a escola, as férias na praia e o dia-a-dia no Japão -, assim como os costumes japoneses - os penteados e os relacionamentos, as casas e a religião, as festas e as comidas, os ideogramas e o haicai. Depois, com a vinda de Tomie ao Brasil, conhecemos um pouco da história da imigração japonesa, da São Paulo na década de 30, da experiência do Japão na Segunda Guerra Mundial e do caminho que Tomie trilhou na pintura (Miranda, 2006, p.35).

Uma breve pesquisa foi feita para melhor entender qual é o nível de conhecimento desta artista, para o público brasileiro. Foram entrevistadas 40 pessoas que variam de 20 a 50 anos e responderam de forma objetiva em um questionário quantitativo de múltipla escolha.

Segue as perguntas com suas opções de resposta e o total analisado em cada questão.

1-Você já ouviu falar da artista plástica Tomie Ohtake?

( ) $\operatorname{sim}$ ( ) não 

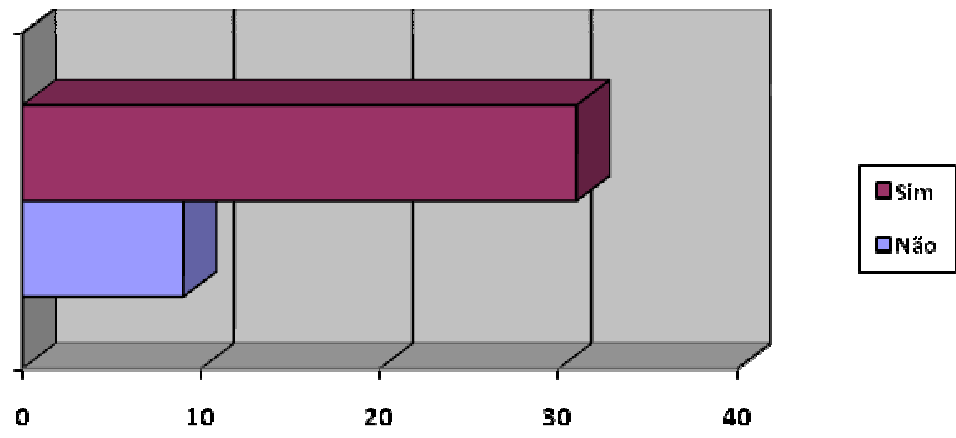

No total 31 pessoas responderam afirmando conhecer a artista Ohtake e 9 disseram não conhecer.

2-Você já foi ao Instituto Tomie Ohtake?

( ) $\operatorname{sim}$ ( ) não
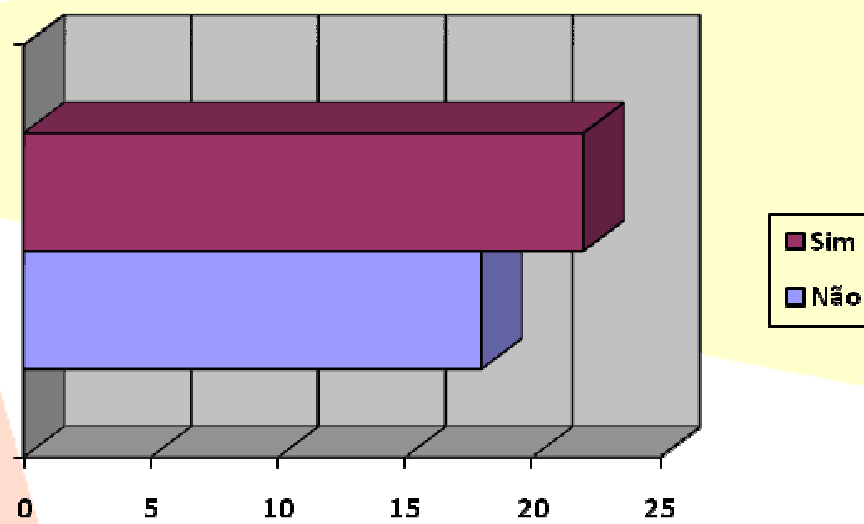

口N

Esta pesquisa mostra que o Instituto Tomie Ohtake foi visitado por 22 pessoas das 40 entrevistadas.

3-Você conhece esta escultura que esta situada na Avenida 23 de Maio? 


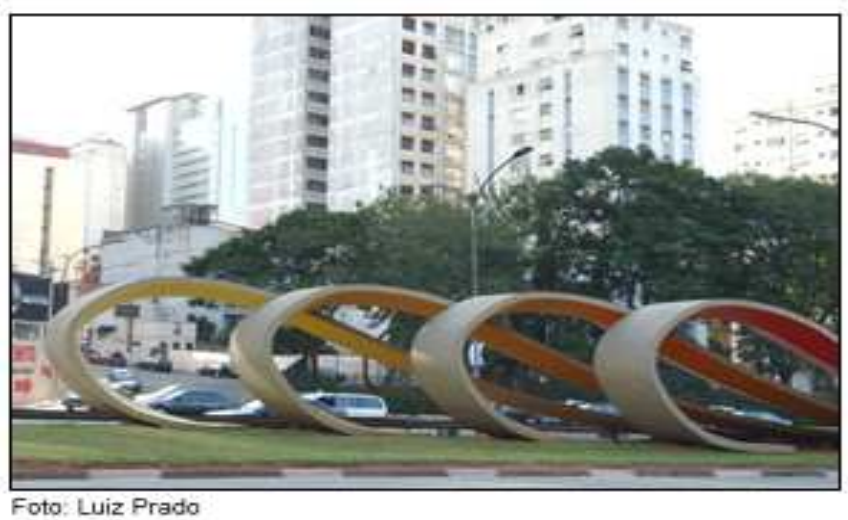

( ) $\operatorname{sim}($ ) não

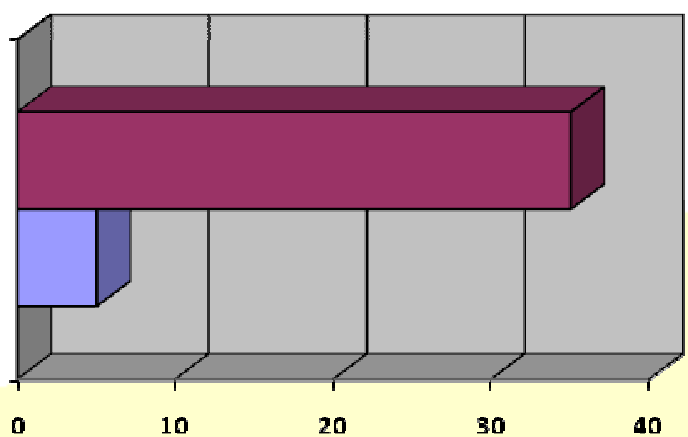

Nesta pesquisa foi mostrada a foto aos entrevistados e revela que 35 pessoas disseram conhecer esta escultura e entre as 5 que não conhecem, 3 disseram que nunca aprestaram atenção e as outras 2 pessoas nunca viram.

A próxima e última questão foi feita com mais opções de escolha para os entrevistados responderem.

4-você sabia que esta escultura foi feita pela artista Tomie Ohtake e dada de presente para a cidade de São Paulo?

( )sabia

( )não sabia que ela fez para a cidade de São Paulo

( )ouvi falar, mas nunca vi a escultura

( )conhecia a escultura e sabia que era um presente para São Paulo, mas não sabia que foi ela quem fez 


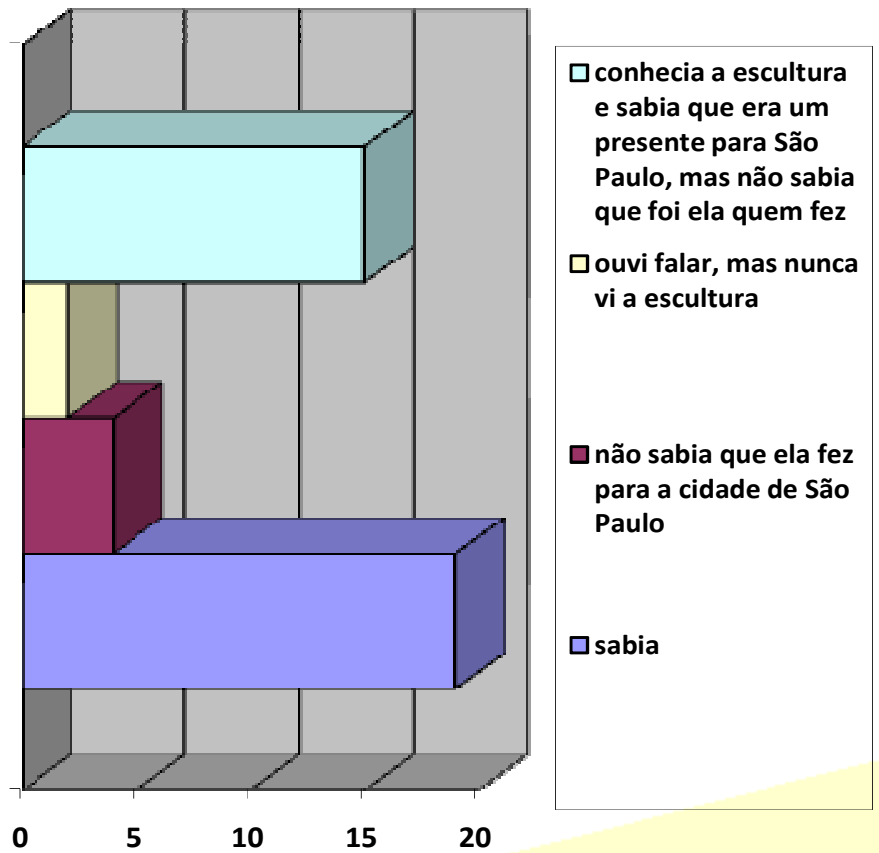

A análise desta questão mostra que as esculturas da artista Ohtake estão bem reconhecidas pelos entrevistados e a informação de ser uma obra dada de presente para a cidade de São Paulo também está reconhecida pelos entrevistados.

Com todos estes dados podemos analisar que a artista Ohtake é muito conhecida pelo público paulista (pois as entrevistas foram feitas na região de São Paulo) e que suas esculturas que são formas de presentear a cidade em que mora atualmente, tem uma resposta muito boa, pois todas as esculturas são apreciadas e elogiadas pelos paulistanos. E não só pela população de São Paulo, como também o público de Santos que recebeu atualmente em um de seus aeroportos uma escultura representando a imigração japonesa como já foi dito acima.

\section{Resultados e Discussão}

O ano de 2008 foi integralmente voltado para a história da imigração japonesa no Brasil, não faltaram exposições que exploram a relação entre os dois países. E não podia ficar de fora um dos principais lugares de exposições que foi feito em homenagem a artista Ohtake e que reúne um dos maiores acervos de artistas de outros países, o Instituto Tomie Ohtake, que tem entre os seus objetivos aproximar o público do leigo ao mais sofisticado - 
dos conceitos chaves relacionados com as principais modalidades expressivas da contemporaneidade, faz parte de sua filosofia ainda estimular a prática artística - do pincel ao pixel - através de cursos e workshops.

Como foi mostrado o contemporâneo ou arte contemporânea surgiu segunda metade do século XX e se prolonga até aos dias de hoje. Após a Segunda Guerra Mundial, sobrepõe-se aos costumes a necessidade da produção em massa. Quando surge um movimento na arte, esse movimento revela-se na pintura, na literatura, na moda, no cinema, e em tantas outras artes tão diferentes.

Sempre quando se menciona a arte contemporânea existe uma associação de algo feito no momento, mas isto não é o que a contemporaneidade quer transmitir, e sim algo em que se pense ou que se propõe um pensamento sobre a própria arte ou uma análise crítica da prática visual.

As novas tecnologias para a arte contemporânea não significam o fim, mas um meio à disposição da liberdade do artista, como Ohtake faz através de seus quadros ou de suas esculturas.

Esta liberdade que foi retratado através das esculturas feitas para a comemoração do centenário da imigração japonesa, realizada no ano de 2008, em que Ohtake quis presentear e mostrar as suas origens para o Brasil. Em todas as esculturas Ohtake tem um significado e todas as obras feitas para o centenário queriam transparecer a liberdade e a leveza do povo Japonês e em cores fortes, mostrar o símbolo do Japão que é o sol nascente e a luta deste povo para conseguir sobreviver a um lugar que nem sabiam que existia.

Uma das obras que Ohtake fez de presente para a comemoração da imigração japonesa, esta situada em Santos, pois se no passado os imigrantes aportaram em Santos (litoral de São Paulo) para entrar no Estado de São Paulo, hoje, eventuais imigrantes e turistas têm o aeroporto como porta de entrada. "Santos representa o passado e o aeroporto, o futuro", afirmou o coordenador da Comissão de Cultura da Associação pelas Comemorações do Centenário da Imigração Japonesa, Reimei Yoshioka.

De acordo com o que disse o coordenador das comemorações do centenário estas obras de Ohtake representam o futuro, ou seja, um pensamento sobre a sua própria arte que é claramente caracterizado como Arte contemporânea.

Por causa de seus traços leves mesmos nas pesadas e grandes esculturas, Ohtake consegue transparecer uma arte que muitos tentam fazer, mas ninguém consegue desenvolver ou criar como ela. 
E através do avanço da tecnologia, que serve de grande ajuda para a arte contemporânea, faz com que as máquinas se adaptem e se tornem cada vez mais necessárias para a confecção das imensas esculturas de Ohtake, fazendo com que arte, inovação e tecnologia, caminhem juntas, uma ajudando e complementando a outra.

\section{Conclusão}

Após a análise de todo este trabalho que aborda vários pontos de história e arte da artista Tomie Ohtake dois grupos podem ser mostrados, pois eles se misturam para ajudar no entendimento da vida e das obras da artista Ohtake.

1- História de vida que ajudou a desabrochar a arte de Tomie Ohtake

2- História e evolução da imigração japonesa no Brasil.

A artista, mais nova de seis irmãos e a única mulher, veio ao Brasil para visitar um irmão e passar apenas uma temporada. Acabou ficando por causa das guerras em que o Japão entrou. Teve de se instalar no Brasil, casou-se e teve dois filhos Ricardo e Ruy Ohtake que é responsável pela moderna casa no Campo Belo onde a artista mora há quase 40 anos.

E com esta vinda para o Brasil, foi onde começou a procurar por um arte hibernada desde pequena, e com o encontro com um artista japones que estava fazendo uma exposição de suas pinturas no Brasil, Ohtake percebeu que podia ir muito além de uma simples escrita em hiragana(é um alfabeto silábico composto por 71 letras inventado pelas mulheres do Japão antigo), katakana(é também um alfabeto silábico de 71 letras, assim como o hiragana, mas quem o inventou foram os monges japoneses.) ou ideogramas em kanji (a palavra "kanji" significa "letra chinesa", ou, num sentido mais amplo, "escrita chinesa".)

Seu modo de expressar a arte no começo era muito tímido, mas depois de muitas práticas e tentativas de esculturas, percebeu que seu modo de "fazer a arte" era único e essa unidade de conhecimento que Ohtake transpassava para as suas obras, fez com que ela conseguisse mostrar a sua cultura para todo o mundo, fazendo várias exposições por vários países.

O motivo principal da imigração japonesa foi devido à superpopulação em que o país se encontrava no século 19. O Japão produzia apenas o alimento que consumia, sem praticamente formação de estoques para períodos difíceis. Qualquer quebra de safra agrícola causava fome generalizada. A política emigratória colocada em prática pelo 
governo japonês tinha como principal objetivo aliviar as tensões sociais devido à escassez de terras cultiváveis e endividamento dos trabalhadores rurais, permitindo assim a implementação de projetos de modernização.

Com a expansão das plantações de café, faltava mão-de-obra na zona rural paulista. Apesar do preconceito, a necessidade de mão-de-obra era muito grande e a vinda de um navio com imigrantes japoneses começou a ser planejada para 1897. Entretanto houve uma crise de superprodução cafeeira nesta época, os preços internacionais desabaram e a vinda de imigrantes foi então desestimulada, mas mesmo com todos estes pontos negativos os japoneses usavam de todo o seu ensinamento e sua cultura para continuar a plantar e ajudar um país chamado Brasil a se erguer com o trabalho imigrante.

A cultura japonesa é muito rica em simbologia e conhecimento. Nas últimas décadas, alguns objetos tradicionais da cultura japonesa foram incorporados ao cotidiano dos brasileiros e fizeram que esta cultura ganhasse merecido destaque e uma incrível evolução no Brasil.

A globalização trouxe o mundo para dentro de nossas casas e estimulou a nossa curiosidade para conhecer (e experimentar) novas culturas. Num país como o Brasil, ao longo destes anos, o tema da imigração gerou muito curiosidade para um povo brasileiro que recebeu estes imigrantes, mas nunca tinham acompanhado esta cultura tão diferente. Como resultado disso registra-se inúmeras publicações e ao mesmo tempo, registra-se uma crescente preocupação dos próprios descendentes ou instituições representativas dos variados grupos imigrantes em preservar e estudar suas raízes revelando uma preocupação em reafirmar sua identidade étnicocultural.

Conclui-se que o enredo deste trabalho, foi direcionado a integrar as obras da artista Ohtake na arte contemporânea, uma arte muito questionada, por pegar elementos de outras épocas e querer sempre estar inovando, e esta inovação fizeram com que a contemporaneidade fosse muito criticada e em poucos momentos fosse bem compreendida.

E neste trabalho foi dado um espaço especial para mostrar um pouco mais desta cultura japonesa que é tão rica e agora tão conhecida pelo povo brasileiro que antigamente recebeu os imigrantes, com algumas propostas mentirosas, porém necessitou da ajuda e acabou integrando ao Brasil uma nova cultura. 


\section{Referências Bibliográficas}

AMARAL, Aracy (Org.). Tomie Ohtake. In: Museu de Arte Contemporânea da Universidade de São Paulo: perfil de um acervo. São Paulo: Techint Engenharia, 1988.

ARRUDA, Vitoria (Coord.). Exposição retrospectiva Tomie Ohtake. Rio de Janeiro: Centro Cultural Banco do Brasil, 2000.

“Guia da Cultura Japonesa em SP”. São Paulo. Ed. JBC, 2004.

REGO, L. e Santos, L., Tomie Ohtake. São Paulo. Ed. Moderna, 2003

REGO, L. e Santos, L., Tomie Ohtake Coleção Mestres das Artes do Brasil. São Paulo. Ed. Moderna Editora, 2001

MIRANDA, A. Tomie: Cerejeiras na noite. São Paulo. Ed. Companhia das Letrinhas, 2006

MORAES, F. Ohtake. São Paulo. Ed. São Paulo, 2001.

MENDONÇA, Casimiro Xavier de. Tomie Ohtake. São Paulo: Editora Ex-Líbris, 1983.

MORAES, Angélica de. Tomie Ohtake recria a tradição. O Estado de São Paulo, São Paulo, 07/02/2003, Caderno 2.

NA ARTE da colônia japonesa no Brasil. São Paulo: MASP, 1988.

\section{Referência Eletrônica}

VICTORINO, Paulo. Tomie Ohtake (1913). São Paulo. Disponível em: <http://www.pitoresco.com.br/brasil/tomie/tomie.htm >Acesso em: 01 maio 2008

Do G1, com informações do Bom Dia São Paulo. Tomie Ohtake prepara surpresa para os cem anos de imigração. São Paulo abril/2008. Disponível em: <http://g1.globo.com/Noticias/0, MUL383891-9980,00. html> Acesso em 02 maio 2008.

EZABELLA, Fernanda. ENTREVISTAS-Esculturas de Tomie Ohtake celebram migração japonesa. O estado de São Paulo, São Paulo fev./2008. Disponível em: <http://www.estadao.com.br/arteelazer/not_art131588,0. htm> 